\title{
CYP2C9*3 Allele
}

National Cancer Institute

\section{Source}

National Cancer Institute. CYP2C9*3 Allele. NCI Thesaurus. Code C45614.

Human CYP2C9*3 allele is located within $10 \mathrm{q} 24$ and is approximately $33 \mathrm{~kb}$ in length. This allele, a variant form of the CYP2C9 wild-type allele, encodes cytochrome P450 2C9*3 protein. The CYP2C9*3 allele exhibits a clinically-relevant SNP (c.1075A>C) in exon 7 that results in an 1359L coding change. This alteration in protein sequence decreases the enzymatic activity of the cytochrome P450 2C9*3 protein. 